JRS vol. L (1960)

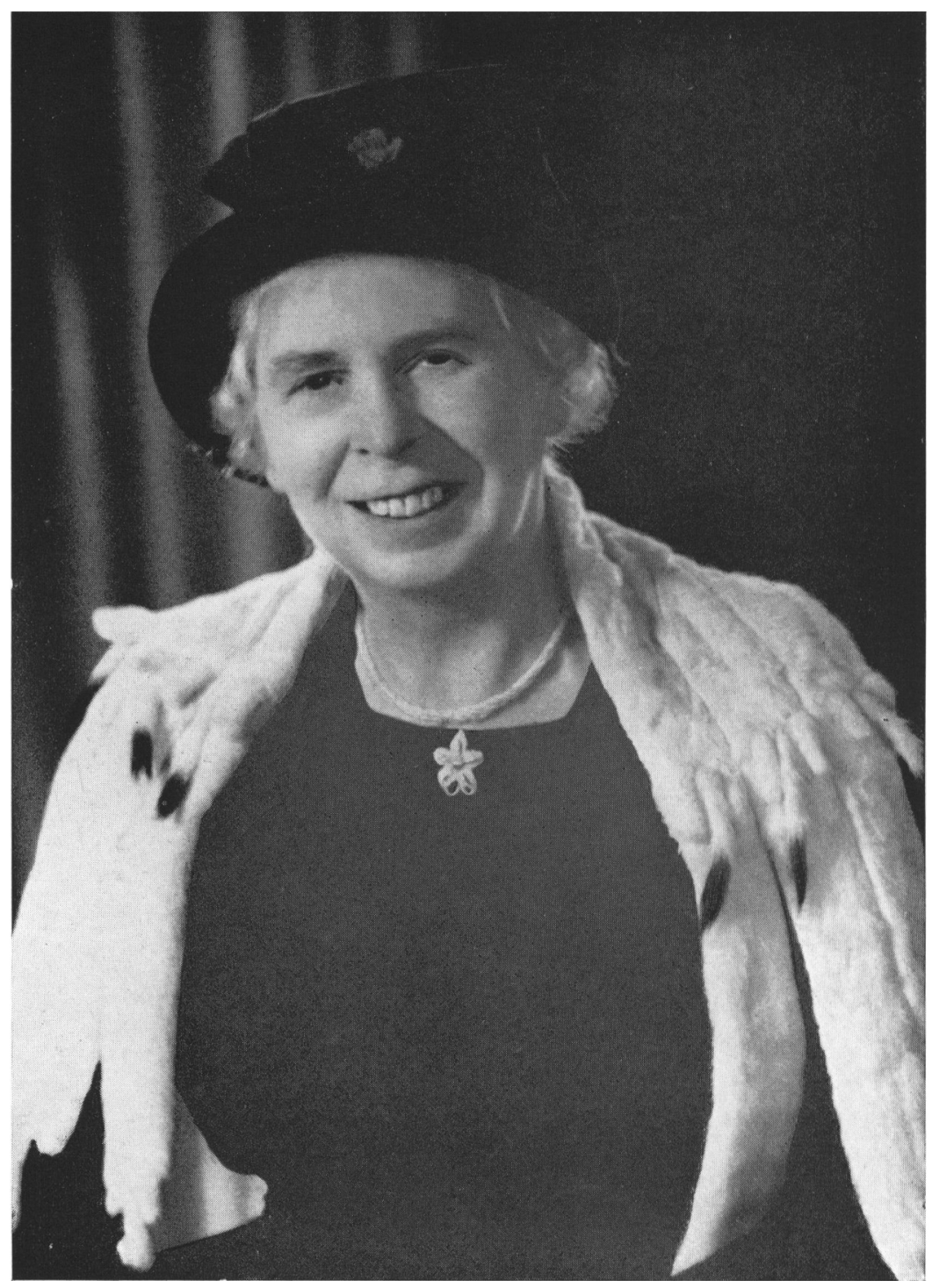

MARGERIE VENABLES TAYLOR 


\section{TO MISS M. V. TAYLOR, C.B.E., M.A., F.S.A., A TRIBUTE}

Labuntur anni : our Editor, Miss Margerie Venables Taylor, has reached her eightieth year, and will have completed it on 2oth January, $196 \mathrm{r}$, attaining thus the period when age becomes an achievement and in her a matter for particular congratulation, since the very statement will take friends by surprise and leave acquaintances astonished. The editorial committee therefore took it upon themselves to include in this Jubilee Number of the fournal a message of congratulation, good wishes, and gratitude to one who was the Society's Secretary for over thirty years (I923-54) and who has been Editor from the same initial date, achieving with this number her fortieth Volume.

Miss Taylor joined the Society in the second year of its existence, though as Professor Haverfield's secretary she had witnessed its very birth : and her connexion with Roman studies goes back to more distant days, when Haverfield was producing the memorable sections of the Victoria County History which did so much to set the tone of Romano-British studies. She came, moreover, from a family and environment immersed in Roman antiquity, inheriting these tastes from her father and her native Chester, and disciplining them at Somerville College where she took the examinations for which women might not then obtain the University degree.

Her achievement on the Society's behalf has been outstanding. The young Society was crippled by the First World War and its consequences. By I923 the Fournal of Roman Studies, its now familiar form already shaped, had fallen behind and was only pulling abreast in the matter of punctual appearance. Since then its progress has been so smooth as to dissemble her good management and zeal which made it possible. The fournal has grown in stature and repute and has stimulated every side of Roman studies. Its very breadth of scope has, indeed, created the problem of accommodating all the interests involved. But the Editor has continuously contrived to hold the balance, with that combination of forthrightness and forbearance which those who know her best know best how to value. Not only contributors to the fournal but many others who have consulted her will recall the application of these qualities to assist their work : meminisse iuvabit.

As joint secretary and editor Miss Taylor was concerned with all sides of the Society's activities. Her own special task, carrying on Haverfield's tradition, has been to compose the annual account of excavation in Roman Britain which forms so valuable a feature of the fournal. As the Second World War drew to its climax, when faith and hope in our studies, driven underground by sterner calls, needed an outlet, it was she who triumphantly brought into existence the congress of classical studies, held jointly with the Hellenic Society and the Classical Association, which has now become a triennial event.

All this was attained against a background of severe financial stringency. Hence the wise determination to make the Society's fournal its outstanding feature, at the price of eschewing or curtailing other activities; a policy which has enhanced not only the standing of the Society but the reputation of our country in Roman studies the world over. Four honours bestowed upon Miss Taylor have recognized her share in this. She was the first of her sex to be elected vice-president of the Society of Antiquaries of London; she was elected in 1946 an honorary Research Fellow of her own Somerville College ; in 1947 she became an honorary member of the Society of Antiquaries of Newcastle upon Tyne ; and in 1948 she was honoured by the award of a C.B.E.

The upsurge of feminine achievement that has been an outstanding feature of the last hundred years is now much taken for granted. Our Editor's generation was in the forefront of the movement, and her own zeal for a scholar's life was of a steady purpose not to be denied. It is permissible to pay this tribute. Not a few women who ardently advocated emancipation lost in the process the pleasanter characteristics of their sex, exchanging daintiness for vehemence and femininity for self-assertion. Miss Taylor (see Frontispiece) has left none of the charm of her generation behind : adding wisdom to charm, she has carried both with her to grace and dignify her ideals while ever revealing her keen and indomitable personality. 